\title{
Effect of nutrition, temperature and photoperiod on the rate of sexual maturation of the field vole (Microtus agrestis)
}

\author{
Norah Spears* and J. R. Clarke* \\ Department of Agricultural Science, University of Oxford, Parks Road, Oxford OX1 3PF, U.K.
}

\begin{abstract}
Summary. Weanling male and female field voles were placed in long or short photoperiods, kept at $18^{\circ} \mathrm{C}$ or $4^{\circ} \mathrm{C}$, and fed (ad libitum) diets containing $24 \%, 16 \%, 8 \%$ and $4 \%$ protein, for 6 weeks. Animals in the long photoperiod were more sexually mature than were animals in the short photoperiod. Temperatures had no effect on females, but did affect males: those kept at $4^{\circ} \mathrm{C}$ had heavier testes and wider seminiferous tubules than those kept at $18^{\circ} \mathrm{C}$. There was little difference between the animals on $24 \%, 16 \%$ and $8 \%$ protein diets. Animals on $4 \%$ protein diets had retarded growth rates and were significantly less sexually mature than those on the other 3 diets, males having smaller testes and seminal vesicles and narrower seminiferous tubules and females having smaller ovaries and uteri.
\end{abstract}

\section{Introduction}

The field vole (Microtus agrestis) is a seasonal breeder, reproducing from spring to autumn each year. The main environmental factor regulating this is photoperiod: long photoperiods promote gonadal development and activity, while short photoperiods result in gonadal regression (Baker \& Ranson, 1932; Clarke \& Kennedy, 1967; Grocock \& Clarke, 1974).

There are, however, some aspects of the reproductive activity of the field vole which cannot be explained by photoperiod alone. For example, it is not uncommon to find reproductively active animals in mid-winter, and this winter breeding has sometimes coincided with an unusually good food supply (Myllymäki, 1977; Hansson, 1984). On the other hand, young born in the late summer or early autumn, when there is still more than $12 \mathrm{~h}$ light per day, usually do not start to mature sexually until the following spring (Clarke \& Forsyth, 1964): it is possible that the particular combination of photoperiod, temperature and nutrition found at that time delays the sexual maturation of these animals.

There are two ways in which diet can influence the reproductive state of animals, (1) through specific chemical compounds such as oestrogens (Moule et al., 1963) or cyclic carbonates (Sanders et al., 1981), or (2) through the overall plane of nutrition, such as the energy or protein content of the food. Low protein diets can cause a reduction in body growth (Anthony \& Edozien, 1975) and affect the reproductive state of the animals (Leathem, 1970). Such diets have been shown to result in smaller and less developed testes in male rats (Horn, 1955), mice (Leathem \& de Feo, 1952) and bulls (Meachem et al., 1964), and retard the growth of uteri and ovaries in female rats (Srebnik et al., 1978).

The field vole is a herbivore, feeding mainly on grass. The protein content of grass varies from around $8 \%$ and $30 \%$ throughout the year (Holmes 1980). Such variations, combined with the variations in ambient temperature that accompany these changes, could be additional factors causing the seasonal breeding exhibited by these animals.

\footnotetext{
*Present address: Department of Zoology, University of Oxford, South Parks Road, Oxford OX1 3PS, U.K.
} 
The following experiment was designed to investigate the separate and interactive influences of photoperiod, protein intake and ambient temperature on the rate of sexual maturation of field voles.

\section{Materials and Methods}

Animals were from the field vole colony maintained in the Department of Agricultural Science, Oxford, on a photoperiodic regimen of $16 \mathrm{~h}$ light: $8 \mathrm{~h}$ dark (16L:8D). The husbandry of this colony is described by Baker \& Clarke (1987). The breeding stock is fed oats and Dixon's diet 41B ad libitum, supplemented twice weekly by carrots and hay, with water constantly available. The experimental animals were fed a pelleted diet, described below, with water constantly available.

The experiment was designed as a $2 \times 2 \times 4$ factorial (Bailey, 1981), the three factors being (1) photoperiod, long (16L:8D) or short (6L:18D); (ii) temperature, warm $\left(18 \pm 2^{\circ} \mathrm{C}\right)$ or cold $\left(4 \pm 2^{\circ} \mathrm{C}\right)$; and (iii) diet protein level, $\mathrm{P} 24$ $(24 \%)$, P $16(16 \%)$, P $8(8 \%)$ or P $4(4 \%)$, making 16 treatments in all. Groups of 16 male and female weanling voles were matched for age ( $16 \pm 1$ days), body weight (8-12 g) and absence of sexual maturity (females with non-perforate vaginas and males with no visible testicular development, a smooth, hairless perineum and a juvenile, small penis). Within each group, or block, of 16 animals, one animal was assigned to each of the treatments. There were 6 such blocks of male voles ( 6 animals per treatment) and 5 of females ( 5 animals per treatment).

The four diets were obtained from Special Diets Service Ltd, Witham, Essex, U.K. The $24 \%$ protein diet used was the Rat and Mouse No. 3 Breeding Diet (gross energy $15.4 \mathrm{MJ} / \mathrm{kg}$ ), and the $16 \%$ protein diet was the Rat and Mouse No. 1 Modified Maintenance Diet. The $8 \%$ and $4 \%$ protein diets were made up by SDS Ltd to be compatible, from the point of view of energy content and minor nutrients, with the Rat and Mouse No. 1 Modified Maintenance Diet (gross energy varied from 14 to $16 \mathrm{MJ} / \mathrm{kg}$ ). All diets were supplied in an expanded pellet form, and were available to the animals ad libitum.

Animals were kept in photoperiod cabinets (Crocock \& Clarke, 1974), equipped with four 25-W tungsten bulbs, giving a light intensity of $188.3 \mathrm{klux}$ at the front of the cage and $27.2 \mathrm{klux}$ in the nest.

Treatments continued for 6 weeks, and animals were then killed in ether vapour. Ovaries, uteri and testes were weighed fresh and fixed in Bouin's fluid. Carcasses of males were preserved in 10\% formalin, and the seminal vesicles were later weighed. Ovaries and testes were embedded in paraffin wax. Serial sections of ovaries and sections of testes, cut at $6 \mu \mathrm{m}$, were stained in Ehrlich's haematoxylin and eosin. Using the follicle classification of Pedersen \& Peters (1968), total numbers of types 6,7 and 8 follicles were counted in pairs of ovaries. All atretic follicles (defined as those containing 5 or more pycnotic nuclei in the granulosa) were also counted. Width of seminiferous tubules was estimated by measuring 15 tubules in each male, and using the mean of these figures in the statistical analysis.

Growth rates were calculated from the difference between final and initial body weights divided by time in days.

The significance of effects of treatments was tested by a Factorial Analysis of Variance (Bailey, 1981).

\section{Results}

\section{Females}

Uterine and ovarian weights. There was a significant photoperiod effect on uterine and ovarian weights $(P<0.001$ for both) such that these organs were heavier in voles kept in long than in short photoperiods (Table 1). Temperature had no effect on either organ. There was no significant difference between the uteri or ovaries of females on the P 24, P 16 or P 8 diet. There was, however, an effect of the P 4 diet. There was a photoperiod $\times$ diet interactive effect on uterine weights $(P<0.001)$, such that, in the long photoperiod only, females fed the $P 4$ diet had significantly smaller uteri than those fed the other 3 diets. In the short photoperiod, females fed the P 4 diet were not significantly different from those fed the P 24, P 16 and P 8 diets. Ovarian weights were depressed by the $\mathbf{P} 4$ diet in the long and short photoperiods, and showed a diet effect $(P<0.001)$.

Ovarian follicle numbers. Ovarian follicle numbers showed no clear pattern, the only significant effect being one of photoperiod on type 8 follicles: females in the long photoperiod had more type 8 follicles than did those in the short photoperiod $(2.52 \pm 0.50$ compared with $0.96 \pm 0.30$ follicles: $P<0 \cdot 01)$. No corpora lutea were found in any of the ovaries.

Growth rates. There was no photoperiod or temperature effect on growth rates, and no effect of diet amongst the P 24, P 16 and P 8 females (Table 2). P 4 females had significantly lower growth rates than $P$ 24, $P 16$ or $P 8$ females in the long and short photoperiods $(P<0.001)$. 
Table 1. Uterine and ovarian weights $(\mathrm{mg})$ of females exposed for 6 weeks to long (16L:8D) or short (6L:18D) photoperiods, kept at $18^{\circ} \mathrm{C}$ or $4^{\circ} \mathrm{C}$, and fed diets of $24 \%(\mathrm{P} 24), 16 \%$ (P16), $8 \%(\mathrm{P} 8)$ or $4 \%(\mathrm{P} 4)$ protein levels

\begin{tabular}{|c|c|c|c|c|c|c|c|c|c|}
\hline \multirow[b]{3}{*}{ Photoperiod } & & \multicolumn{8}{|c|}{ Temperature and diet } \\
\hline & & \multicolumn{4}{|c|}{$18^{\circ} \mathrm{C}$} & \multicolumn{4}{|c|}{$4^{\circ} \mathrm{C}$} \\
\hline & & P24 & P16 & P8 & P4 & P24 & P16 & P8 & P4 \\
\hline \multirow[t]{2}{*}{ Long } & Uterus & $\begin{array}{r}19.6 \\
\pm 0.7\end{array}$ & $\begin{array}{r}47.5 \\
\pm 7.6\end{array}$ & $\begin{array}{r}19.3 \\
+4.9\end{array}$ & $\begin{array}{r}5.7 \\
+0.6\end{array}$ & $\begin{array}{r}25 \cdot 3 \\
\pm 8 \cdot 8\end{array}$ & $\begin{array}{r}25.8 \\
\pm 9.8\end{array}$ & $\begin{array}{r}26.9 \\
\pm 9.8\end{array}$ & $\begin{array}{r}6 \cdot 0 \\
\pm 0 \cdot 4\end{array}$ \\
\hline & Ovary & $\begin{array}{r}3.32 \\
\pm 0.55\end{array}$ & $\begin{array}{r}3.56 \\
\pm 0.37\end{array}$ & $\begin{array}{r}3.36 \\
\pm 0.39\end{array}$ & $\begin{array}{r}1.42 \\
\pm 0.18\end{array}$ & $\begin{array}{r}3.80 \\
\pm 0.51\end{array}$ & $\begin{array}{r}4.52 \\
\pm 0.26\end{array}$ & $\begin{array}{r}4.10 \\
\pm 0.56\end{array}$ & $\begin{array}{r}2.08 \\
\pm 0.45\end{array}$ \\
\hline \multirow[t]{2}{*}{ Short } & Uterus & $\begin{array}{r}7.9 \\
\pm 1.0\end{array}$ & $\begin{array}{r}9.5 \\
+1.8\end{array}$ & $\begin{array}{r}7.8 \\
+1.0\end{array}$ & $\begin{array}{r}5.2 \\
\pm 0.7\end{array}$ & $\begin{array}{r}7 \cdot 2 \\
\pm 1.0\end{array}$ & $\begin{array}{r}6.4 \\
\pm 0.5\end{array}$ & $\begin{array}{r}10 \cdot 8 \\
\pm 4.0\end{array}$ & $\begin{array}{r}6.8 \\
+1.5\end{array}$ \\
\hline & Ovary & $\begin{array}{r}2.08 \\
\pm 0.36\end{array}$ & $\begin{array}{r}2.36 \\
\pm 0.36\end{array}$ & $\begin{array}{r}3 \cdot 12 \\
\pm 0 \cdot 18\end{array}$ & $\begin{array}{r}1.32 \\
\pm 0.20\end{array}$ & $\begin{array}{r}2.04 \\
\pm 0.26\end{array}$ & $\begin{array}{r}2.40 \\
\pm 0.22\end{array}$ & $\begin{array}{r}2.42 \\
\pm 0.42\end{array}$ & $\begin{array}{r}1.72 \\
\pm 0.14\end{array}$ \\
\hline
\end{tabular}

Values are mean \pm s.e.m., 5 animals per treatment.

Table 2. Growth rates ( $\mathrm{g} /$ day) of females ( 5 animals per treatment) and males ( 6 animals per treatment) exposed for 6 weeks to long (16L:8D) or short (6L:18D) photoperiods, kept at $18^{\circ} \mathrm{C}$ or $4^{\circ} \mathrm{C}$, and fed diets of $24 \%$ (P24), 16\% (P16), 8\% (P8) or 4\% (P4) protein levels

\begin{tabular}{|c|c|c|c|c|c|c|c|c|c|}
\hline \multirow[b]{3}{*}{ Photoperiod } & \multirow[b]{3}{*}{ Sex } & \multicolumn{8}{|c|}{ Temperature and diet } \\
\hline & & \multicolumn{4}{|c|}{$18^{\circ} \mathrm{C}$} & \multicolumn{4}{|c|}{$4^{\circ} \mathrm{C}$} \\
\hline & & $\mathrm{P} 24$ & P16 & P8 & $\mathrm{P} 4$ & $\mathbf{P} 24$ & P16 & P8 & P4 \\
\hline \multirow[t]{2}{*}{ Long } & Females & $\begin{array}{r}0.34 \\
\pm 0.03\end{array}$ & $\begin{array}{r}0.33 \\
\pm 0.06\end{array}$ & $\begin{array}{r}0.34 \\
\pm 0.05\end{array}$ & $\begin{array}{r}0.09 \\
\pm 0.04\end{array}$ & $\begin{array}{r}0.37 \\
\pm 0.03\end{array}$ & $\begin{array}{r}0.36 \\
\pm 0.02\end{array}$ & $\begin{array}{r}0.36 \\
\pm 0.03\end{array}$ & $\begin{array}{r}0.13 \\
\pm 0.01\end{array}$ \\
\hline & Males & $\begin{array}{r}0.43 \\
\pm 0.05\end{array}$ & $\begin{array}{r}0.38 \\
\pm 0.05\end{array}$ & $\begin{array}{r}0.34 \\
\pm 0.03\end{array}$ & $\begin{array}{r}0.08 \\
\pm 0.04\end{array}$ & $\begin{array}{r}0.48 \\
+0.04\end{array}$ & $\begin{array}{r}0.42 \\
\pm 0.03\end{array}$ & $\begin{array}{r}0.42 \\
\pm 0.03\end{array}$ & $\begin{array}{r}0.19 \\
\pm 0.04\end{array}$ \\
\hline \multirow[t]{2}{*}{ Short } & Females & $\begin{array}{r}0.31 \\
\pm 0.04\end{array}$ & $\begin{array}{r}0.32 \\
\pm 0.03\end{array}$ & $\begin{array}{r}0.34 \\
\pm 0.05\end{array}$ & $\begin{array}{r}0.13 \\
\pm 0.03\end{array}$ & $\begin{array}{r}0.36 \\
\pm 0.04\end{array}$ & $\begin{array}{r}0.39 \\
\pm 0.04\end{array}$ & $\begin{array}{r}0.33 \\
\pm 0.04\end{array}$ & $\begin{array}{r}0.18 \\
\pm 0.02\end{array}$ \\
\hline & Males & $\begin{array}{r}0.42 \\
\pm 0.05\end{array}$ & $\begin{array}{r}0.39 \\
\pm 0.05\end{array}$ & $\begin{array}{r}0.38 \\
\pm 0.03\end{array}$ & $\begin{array}{r}0.08 \\
\pm 0.02\end{array}$ & $\begin{array}{r}0.34 \\
\pm 0.04\end{array}$ & $\begin{array}{r}0.28 \\
\pm 0.03\end{array}$ & $\begin{array}{r}0.35 \\
\pm 0.03\end{array}$ & $\begin{array}{r}0.15 \\
\pm 0.01\end{array}$ \\
\hline
\end{tabular}

Values are mean \pm s.e.m.

\section{Males}

Testicular and seminal vesicle weights. Males in the long photoperiod had heavier testes and seminal vesicles than those in the short photoperiod $(P<0.001$ for both) (Table 3), although several of the males in the short photoperiod did have testicular weights ranging from 130 to $300 \mathrm{mg}$. There was no significant difference in testicular or seminal vesicle weights between males on diets P 24, P 16 and P 8 . There was a photoperiod $\times$ diet interaction on both organs $(P<0.001$ and $P<0.01$ respectively) such that, in the long photoperiod only, males fed the $4 \%$ protein diet had significantly smaller testes and seminal vesicles than those fed the other 3 diets. In the short photoperiod, males fed the $4 \%$ protein diet were not significantly different from those fed the $24 \%$, $16 \%$ and $8 \%$ diets. Temperature had a significant effect on testicular weights: males kept at $4{ }^{\circ} \mathrm{C}$ had heavier testes than males kept at $18^{\circ} \mathrm{C}(P<0.01)$. 
Table 3. Paired testicular and seminal vesicle weights $(\mathrm{mg})$ and seminiferous tubule widths $(\mu \mathrm{m})$ of males exposed for 6 weeks to long (16L:8D) or short (6L:18D) photoperiods, kept at $18^{\circ} \mathrm{C}$ or $4^{\circ} \mathrm{C}$, and fed diets of $24 \%(\mathrm{P} 24), 16 \%(\mathrm{P} 16), 8 \%(\mathrm{P} 8)$ or $4 \%(\mathrm{P} 4)$ protein levels

\begin{tabular}{|c|c|c|c|c|c|c|c|c|c|}
\hline \multirow[b]{3}{*}{ Photoperiod } & & \multicolumn{8}{|c|}{ Temperature and diet } \\
\hline & & \multicolumn{4}{|c|}{$18^{\circ} \mathrm{C}$} & \multicolumn{4}{|c|}{$4^{\circ} \mathrm{C}$} \\
\hline & & P24 & P16 & P8 & P4 & P24 & P16 & P8 & P4 \\
\hline \multirow[t]{3}{*}{ Long } & Testes & $\begin{array}{r}338 \\
\pm 31\end{array}$ & $\begin{array}{l}340 \\
\pm 36\end{array}$ & $\begin{array}{r}281 \\
\pm 29\end{array}$ & $\begin{array}{r}85 \\
\pm 26\end{array}$ & $\begin{array}{r}399 \\
\pm 47\end{array}$ & $\begin{array}{r}321 \\
\pm 36\end{array}$ & $\begin{array}{r}361 \\
\pm 17\end{array}$ & $\begin{array}{r}198 \\
\pm 48\end{array}$ \\
\hline & $\begin{array}{l}\text { Seminal } \\
\text { vesicles }\end{array}$ & $\begin{array}{r}129.9 \\
\pm 40.1\end{array}$ & $\begin{array}{r}112.4 \\
\pm 38.9\end{array}$ & $\begin{array}{r}80.2 \\
+34.7\end{array}$ & $\begin{array}{r}13.6 \\
+11.7\end{array}$ & $\begin{array}{r}122.6 \\
\pm 33.6\end{array}$ & $\begin{array}{r}113.8 \\
\pm 23.2\end{array}$ & $\begin{array}{r}93.1 \\
\pm 33.8\end{array}$ & $\begin{array}{r}16 \cdot 7 \\
+6 \cdot 9\end{array}$ \\
\hline & Tubules & $\begin{array}{l}185 \cdot 7 \\
\pm 7 \cdot 4\end{array}$ & $\begin{array}{l}187.5 \\
\pm 5.0\end{array}$ & $\begin{array}{l}138 \cdot 8 \\
\pm 9 \cdot 7\end{array}$ & $\begin{array}{r}104 \cdot 0 \\
\pm 12 \cdot 3\end{array}$ & $\begin{array}{r}200 \cdot 5 \\
\pm 7 \cdot 1\end{array}$ & $\begin{array}{l}185.7 \\
\pm 6.5\end{array}$ & $\begin{array}{l}164.7 \\
\pm 7.5\end{array}$ & $\begin{array}{r}148 \cdot 0 \\
\pm 17 \cdot 6\end{array}$ \\
\hline \multirow[t]{3}{*}{ Short } & Testes & $\begin{array}{r}37 \\
\pm 9\end{array}$ & $\begin{array}{r}40 \\
\pm 8\end{array}$ & $\begin{array}{r}36 \\
\pm 4\end{array}$ & $\begin{array}{r}23 \\
\pm 12\end{array}$ & $\begin{array}{r}63 \\
+20\end{array}$ & $\begin{array}{r}35 \\
\pm 9\end{array}$ & $\begin{array}{r}97 \\
+46\end{array}$ & $\begin{array}{r}25 \\
\pm 6\end{array}$ \\
\hline & $\begin{array}{l}\text { Seminal } \\
\text { vesicles }\end{array}$ & $\begin{array}{r}2.6 \\
\pm 0.2\end{array}$ & $\begin{array}{r}3 \cdot 1 \\
\pm 0.7\end{array}$ & $\begin{array}{r}2.7 \\
\pm 0.6\end{array}$ & $\begin{array}{r}1.8 \\
\pm 0.2\end{array}$ & $\begin{array}{r}3.4 \\
\pm 0.7\end{array}$ & $\begin{array}{r}2 \cdot 2 \\
\pm 0 \cdot 2\end{array}$ & $\begin{array}{r}8.6 \\
\pm 5.8\end{array}$ & $\begin{array}{r}1.8 \\
\pm 0.4\end{array}$ \\
\hline & Tubules & $\begin{array}{r}87.7 \\
\pm 8.9\end{array}$ & $\begin{array}{r}90 \cdot 2 \\
\pm 4 \cdot 1\end{array}$ & $\begin{array}{r}77.8 \\
\pm 6.6\end{array}$ & $\begin{array}{r}62 \cdot 2 \\
\pm 9 \cdot 1\end{array}$ & $\begin{array}{r}91.5 \\
\pm 13.6\end{array}$ & $\begin{array}{r}86.2 \\
\pm 6.6\end{array}$ & $\begin{array}{r}91.7 \\
\pm 16.0\end{array}$ & $\begin{array}{r}73.2 \\
\pm 6.7\end{array}$ \\
\hline
\end{tabular}

Values are mean \pm s.e.m., 6 animals per treatment.

Seminiferous tubule width. As with testicular weights, the seminiferous tubules showed a photoperiod effect $(P<0.001)$, with males in the long photoperiod having wider tubules than those in the short photoperiod, and a temperature effect $(P<0.01)$, with males kept at $4^{\circ} \mathrm{C}$ having wider tubules than those kept at $18^{\circ} \mathrm{C}$ (Table 3). In the long photoperiod, P 24, P 16 and P 8 males had wider tubules than P 4 males $(P<0.001)$. However, a difference also appeared between the $P 24$, $P 16$ and P 8 males: the tubules of $P 8$ males were narrower than those of P 24 and P 16 males $(P<0 \cdot 001)$. As with the testicular and seminal vesicle weights, there was no effect of diet in the short photoperiod, and therefore the diet effect was shown as a photoperiod $x$ diet interaction.

Growth rates. There was a photoperiod effect on growth rates only amongst the animals living at $4^{\circ} \mathrm{C}$ (Table 2): males in the long photoperiod had a higher growth rate than those in the short photoperiod (photoperiod $\times$ temperature interaction: $P<0.05$ ). There was no diet effect amongst the P 24, P 16 and P 8 males, but there was an effect of diet at the P 4 level, in the long and short photoperiods, such that P 4 males had lower growth rates than P 24, P 16 and P 8 males $(P<0.001)$.

\section{Discussion}

The well established effect of photoperiod upon the sexual development of field voles has again been demonstrated here for various measures of ovarian and testicular activity.

In some laboratory populations of deer mice and white-footed mice, sexual development in a fairly large proportion $(20-40 \%)$ of males is not inhibited by short photoperiods (Johnston \& Zucker, 1980; Beasley et al., 1981; Desjardins \& Lopez, 1983). This was also found here, and has been described in the past for the field vole, although the proportion of animals not inhibited appears to be smaller (Clarke, 1977; Spears \& Clarke, 1987).

Temperature had no effect on the sexual maturation or the growth rates of the females. Temperatures did, however, have an effect on males: those kept at $4^{\circ} \mathrm{C}$ had significantly larger testes and 
significantly wider seminiferous tubules than did those kept at $18^{\circ} \mathrm{C}$. There was no interaction between diet and temperature on the sexual maturation of males or females.

Protein levels in grass vary from around $30 \%$ in eary spring, when the grass is starting to grow, to its lowest of about $8 \%$ in late summer, after flowering (Dent \& Aldrich, 1968; Green et al., 1971; Holmes, 1980). In this experiment, there was surprisingly little difference between the animals fed diets containing $24 \%, 16 \%$ or $8 \%$ protein. Indeed, the only indication of any diet effect amongst these groups was that the P 24 and P 16 males had wider seminiferous tubules than the P 8 males. In general, therefore, the $8 \%$ protein diet, corresponding to late summer/early autumn levels of protein (a time of year when weanlings do not mature sexually inspite of the long photoperiod), had little effect on the sexual maturity of the animals. Although earlier studies considered that most Microtus species needed a diet containing about $13 \%$ protein, more recently minimum protein requirements have been set at $8 \%$ (Batzli, 1985). It is possible that the P8 animals compensated for the low protein content of the diet by eating more food. Unfortunately, it was not possible to measure food intake, due to the large and variable amount of spillage by the animals. However, with the exception of some arctic species, food supply is rarely thought to be limiting to microtine rodents (Southern, 1979), and therefore animals in the wild would be able to increase food intake in response to low food quality. Laboratory rats fed low (1 or $2 \%$ ) protein diets have been found to have a food intake lower than that of animals fed $20 \%$ protein diets, with food consumption per gram body weight remaining the same (Crompton et al., 1981).

When protein levels were reduced to $4 \%$ (roughly the level of protein in straw), a strong dietary effect was found: both males and females fed the $P 4$ diet were less sexually mature and had slower growth rates than did the P 24, P 16 and P 8 animals. Uterine, testicular and seminal vesicle weights were reduced by the $\mathrm{P} 4$ diet only amongst long photoperiod animals, so that there was a photoperiod $\times$ diet interactive effect. Female ovarian weights and growth rates and male growth rates were reduced by the $\mathrm{P} 4$ diet in the long and short photoperiod, and did not show a photoperiod $x$ diet interactive effect. It seems likely, therefore, that where there was no diet effect in the short photoperiod, this was because uterine, testicular and seminal vesicle weights were already suppressed to a basal level by the short photoperiod. Indeed, the organ weights of the short photoperiod animals on all diets and at both temperatures compare with those of animals in the wild in winter (Clarke \& Forsyth, 1964).

Quantitative and qualitative changes in the diet, without regard to the chemical composition of the food, has been shown to alter the gonadal activity of several species of rodents. Grocock (1972), working with male field voles kept at $18^{\circ} \mathrm{C}$, found that reducing the diet of whole oats and carrots by $50 \%$ caused a significant decline in testicular weight in long and short photoperiods. Testicular regression also occurs in deer mice (Peromyscus maniculatus) given a restricted diet (Desjardins \& Lopez, 1983; Blank \& Desjardins, 1984). An interactive effect of photoperiod, diet and temperature or of photoperiod and diet on testicular weights has been observed in male Australian bush rats (Rattus fuscipes) and golden hamsters (Mesocricetus auratus) (Irby et al., 1984; Johnson \& Hoffman, 1985). On the other hand, gonadal activity of house mice seems to be little affected by low protein diets, or by quite considerable restriction of diet, particularly amongst males (Vandenbergh et al., 1972; Hamilton \& Bronson, 1985).

Under laboratory conditions, supplementing the pelleted food of two species of Microtus with lettuce or fresh spinach caused increased sexual development compared with animals fed pellets alone (Berger \& Negus, 1974; Nelson et al., 1983). The P 24 pellets used in this experiment are also probably not, on their own, an optimal diet. A comparison of the animals in this experiment with voles of the same age from a previous experiment, fed whole oats, pellets and carrots, shows that the P 24 animals described here had smaller testes and uteri, and lower growth rates, in long and short photoperiods (Spears \& Clarke, 1986).

Supplemental feeding also affects the reproductive activity of wild populations of Microtus (Negus \& Berger, 1977; Cole \& Batzli, 1978; Taitt \& Krebs, 1981), although such feeding appears 
not to affect the 3-4-year population cycles exhibited by many species of Microtus (Cole \& Batzli, 1978; Abdellatif et al., 1982).

Growth rates of females were unaffected by photoperiod, but males kept at $4{ }^{\circ} \mathrm{C}$ had reduced growth rates in short photoperiods. Consequently, there was a photoperiod $\times$ temperature interactive effect on male growth rates. Decreased growth rates of voles in short photoperiod have already been reported (Dark \& Zucker, 1984; Spears \& Clarke, 1986), although such an effect does not always occur (Wunder, 1984; Spears \& Clarke, 1987).

The temperature effect found here, such that males kept at $4^{\circ} \mathrm{C}$ had heavier testes than those kept at $18^{\circ} \mathrm{C}$, was unexpected. Earlier experiments with field voles found no significant effect of temperature on males or females (Clarke \& Kennedy, 1967). In addition, it is not clear why low temperatures (of around $4^{\circ} \mathrm{C}$ ) should stimulate sexual maturation. Low temperatures suppress reproductive productivity in house mice (Pryor \& Bronson, 1981), delaying the onset of breeding and increasing the inter-birth interval (Barnett, 1973), result in reduced testicular weights in rats and golden hamsters (Heroux \& Campbell, 1959; Hoffman et al., 1965), and, when applied in combination with short photoperiods, cause testicular regression in deer mice (Desjardins \& Lopez, 1983). However, the increase in testicular weights by low temperatures has been described before, in the red-backed vole, the desert pocket mouse and in one strain of deer mouse (Roth, 1974; Kenagy \& Bartholemew, 1981; Bronson \& Pryor, 1983).

It is known that field voles from laboratory stock are not exactly representative of the F1 generation of wild voles in their sexual development (Spears \& Clarke, 1987). Any application of the present results to wild vole populations will, therefore, need a degree of caution. It does, however, seem likely that neither the onset nor the cessation of breeding is regulated via the protein content of the diet in field voles in the wild. Protein had to be reduced to a level below that found in winter grass before it had an effect on the reproductive state of the laboratory voles, and no interaction between diet and temperature was found. Any role of nutrition in regulating the breeding season may, therefore, need to be looked for amongst other components of the diet such as energy levels or specific 'signals'.

N.S. was supported by a Natural Environment Research Council Research Studentship. We thank Valerie Petts and Janet Evans for technical assistance.

\section{References}

Abdellatif, E.M., Armitage, K.B., Gaines, M.S. \& Johnson, M.L. (1982) The effect of watering on a prairie vole population. Acta theriol. 27, 243-255.

Anthony, L.E. \& Edozien, J.C. (1975) Experimental protein and energy deficiencies in the rat. J. Nutrit. 105, 631-648.

Bailey, N.T.J. (1981) Statistical Methods in Biology. Hodder \& Stoughton, London.

Baker, J.P. \& Clarke, J.R. (1987) Voles. In UFAW Handbook on the Care and Management of Laboratory Animals ch. 2, pp. 331-345. Ed. T. B. Poole. Longman, Harlow.

Baker, J.R. \& Ranson, R.M. (1932) Factors affecting the breeding season of the field mouse (Microtus agrestis). Part I. Light. Proc. R. Soc. B 110, 313-322.

Barnett, S.A. (1973) Maternal processes in the coldadaptation of mice. Biol. Rev. 48, 477-508.

Batzli, G.O. (1985) Nutrition. In Biology of New World Microtines, pp. 779-811. Ed. R. H. Tamarin. Special Publication No. 8. The American Society of Mammalogists.

Beasley, L.J., Johnston, P.G. \& Zucker, I. (1981) Photoperiodic regulation of reproduction in post partum Peromyscus leucopus. Biol. Reprod. 24, 962-966.
Berger, P.J. \& Negus, N.C. (1974) Influences of dietary supplements of fresh lettuce on ovariectomised Microtus montanus. J. Mammal. 55, 747-750.

Blank, J.L. \& Desjardins, C. (I984) Spermatogenesis is modified by food intake in mice. Biol. Reprod. 30, $410-415$.

Bronson, F.H. \& Pryor, S. (1983) Temperature and reproductive success in rodents living at different altitudes. Biol. Reprod. 29, 72-80.

Clarke, J.R. (1977) Long and short term changes in gonadal activity of field and bank voles. Oikos 29, $457-467$.

Clarke, J.R. \& Forsyth, I.A. (1964) Seasonal changes in the gonads and accessory reproductive organs of the vole (Microtus agrestis). Gen. comp. Endocr. 4, 233-242.

Clarke, J.R. \& Kennedy, J.P. (1967) Effect of light and temperature upon gonadal activity in the vole ( $\mathrm{Mic}$ rotus agrestis). Gen. comp. Endocr. 8, 474488.

Cole, F.R. \& Batzli, G.O. (1978) Influence of supplemental feeding on a vole population. J. Mammal. 59, 809-819.

Crompton, D.W.T., Walters, D.E. \& Arnold, S. (1981) Changes in the food intake and body weight of 
protein-malnourished rats infected with Nippostrongylus brasiliensis (Nematoda). Parasitology 82, 23-28.

Dark, J. \& Zucker, I. (1984) Gonadal and photoperiodic control of seasonal body weight changes in male voles. Am. J. Physiol. 247, 84-88.

Dent, J.W. \& Aldrich, D.T.A. (1968) Systematic testing of quality in grass varieties: II. J. Br. Grassl. Soc. 23, 13-19.

Desjardins, C. \& Lopez, M.J. (1983) Environmental cues evoke differential responses in pituitary-testicular function in deer mice. Endocrinology 112, 1398-1406.

Green, J.O., Corrall, A.J. \& Terry, R.A. (1971) Grass species and varieties. Grassland Research Institute Technical Report No. 8.

Grocock, C.A. (1972) The influence of some environmental factors on the testis of the vole, with particular reference to spermatogenesis. D.Phil. thesis, University of Oxford.

Grocock, C.A. \& Clarke, J.R. (1974) Photoperiodic control of testis activity in the vole, Microtus agrestis. J. Reprod. Fert. 39, 337-347.

Hamilton, G.D. \& Bronson, F.H. (1985) Food restriction and reproductive development in wild house mice. Biol. Reprod. 32, 773-778.

Hansson, L. (1984) Winter reproduction of small mammals in relation to food conditions and population dynamics. In Winter Ecology of Small Mammals, pp. 225-234. Ed. J. F. Merritt. Special Publication of Carnegie Museum of Natural History No. 10.

Heroux, O. \& Campbell, J.S. (1959) Comparison between seasonal and thermal acclimitization in white rats. Can. J. Biochem. Physiol. 37, 1263-1269.

Hofiman, R.A., Hester, R.J. \& Towns, C. (1965) Effect of light and temperature on the endocrine system of the golden hamster (Mesocricetus auratus). Comp. Biochem. Physiol. 15, 525-533.

Holmes, W. (1980) Grass: it's Production and Utilization. Blackwells, London.

Horn, E.H. (1955) Nutritional and hormonal influences upon reproductive maturation, organ weights and histochemistry of the immature male rat. Endocrinology 57, 399-408.

Irby, D.C., Kerr, J.B., Risbridger, G.P. \& de Kretser, D.M. (1984) Seasonally and experimentally induced changes in the testicular function of the Australian bush rat (Rattus fuscipes). J. Reprod. Fert. 70, 657-666.

Johnson, L.B. \& Hoffman, R.A. (1985) Interaction of diet and photoperiod on growth and reproduction in male golden hamsters. Growth 49, 380-399.

Johnston, P.G. \& Zucker, I. (1980) Photoperiodic regulation of the testes of adult white-footed mice (Peromyscus leucopus). Biol. Reprod. 23, 859-866.

Kenagy, G.J. \& Bartholemew, G.A. (1981) Effects of daylength, temperature and green food on testicular development in a desert pocket mouse Perognathus formosus. Physiol. Zool. 54, 62-73.

Leathem, J.H. (1970) Nutrition. In The Testis, vol. 3, pp. 170-205. Eds A. D. Johnson, W. R. Gomes \& N. L. VanDemark. Academic Press, New York.

Leathem, J.H. \& de Feo, V.J. (1952) Responses of the mouse gonad to equine pituitary gonadotrophin as influenced by dietary protein restriction. Anat. Rec. 112, 356-361.
Meacham, T.N., Warnick, A.C., Cunha, T.J., Hentges, J.F. \& Shirley, R.L. (1964) Hematological and histological changes in young beef bulls fed low protein rations. J. Anim. Sci. 23, 380-384.

Moule, G.R., Braden, A.W.H. \& Lamond, D.R. (1963) The significance of oestrogens in pasture plants in relation to animal production. Anim. Breed. Abstr. 31, 139-157.

Myllymäki, A. (1977) Demographic mechanisms in the fluctuating populations of the field vole Microtus agrestis. Oikos 29, 468-493.

Negus, N.C. \& Berger, P.J. (1977) Experimental triggering of reproduction in a natural population of Microtus montanus. Science, N.Y. 196, 1230-1231.

Nelson, R.J., Dark, J. \& Zucker, I. (1983) Influence of photoperiod, nutrition and water availability on reproduction of male California voles (Microtus californicus). J. Reprod. Fert. 69, 473-477.

Pedersen, T. \& Peters, H. (1968) Proposal for a classification of oocytes and follicles in the mouse ovary. $J$. Reprod. Fert. 17, 555-557.

Pryor, S. \& Bronson, F.H. (1981) Relative and combined effects of low temperature, poor diet and short photoperiod on the productivity of wild house mice. Biol. Reprod. 25, 734-743.

Roth, R.R. (1974) The effect of temperature and light combinations upon the gonads of male red-back voles. Biol. Reprod. 10, 309-314.

Sanders, E.H., Gardener, P.D., Berger, P.J. \& Negus, N.C. (1981) 6-Methoxybenzoxazolinone: a plant derivative that stimulates reproduction in Microtus montanus. Science, N.Y. 214, 67-69.

Southern, H.N. (1979) The stability and instability of small mammal populations. In Ecology of Small Mammals, pp. 103-134. Ed. D. M. Stoddart. Chapman and Hall, London.

Spears, N. \& Clarke, J.R. (1986) Effect of male presence and of photoperiod on the sexual maturation of the field vole (Microtus agrestis). J. Reprod. Fert. 78, 231-238.

Spears, N. \& Clarke, J.R. (1987) Comparison of the gonadal response of wild and laboratory field voles (Microtus agrestis) to different photoperiods. $J$. Reprod. Fert. 79, 75-81.

Srebnik, H.H., Fletcher, W.H. \& Campbell, G.A. (1978) Neuroendocrine aspects of reproduction in experimental malnutrition. In Environmental Endocrino$\log y$, pp. 306-312. Eds I. Assenmacher \& D. S. Farner. Springer-Verlag, New York.

Taitt, M.J. \& Krebs, C.J. (198I) The effect of extra food on small rodent populations. II. Voles (Microtus townsendii). J. Anim. Ecol. 50, 125-37.

Vandenbergh, J.G., Drickamer, L.C. \& Colby, D.R. (1972) Social and dietary factors in the sexual maturation of female mice. J. Reprod. Fert. 28, 397-406.

Wunder, B.A. (1984) Strategies for, and environmental cueing mechanisms of, seasonal changes in thermoregulatory parameters of small mammals. In Winter Ecology of Small Mammals, pp. 165-172. Ed. J. F. Merritt. Special Publication of Carnegie Museum of Natural History No. 10.

Received 18 August 1986 